\title{
The Production and comparison of fuel properties on Biodiesel with Alternative Fuel : A Review
}

\author{
Norazwan Azman ${ }^{1, a^{*}}$, Bukhari Manshoor ${ }^{1, b}$, Amir Khalid ${ }^{1, c}$ \\ ${ }^{1}$ Automotive Research Group (ARG), Centre for Energy and Industrial Environment Studies \\ (CEIES), Universiti Tun Hussein Onn Malaysia, Parit Raja, Batu Pahat, 86400 Johor, Malaysia. \\ aazwanazman1989@gmail.com, bbukhari@uthm.edu.my, camirk@uthm.edu.my
}

\section{Keywords: Biodiesel, Alternative Fuel, Fuel Properties}

\begin{abstract}
The energy is the most of the human existence. Consumption fossil fuels has grown substantially and consumption the energy sources that is seen as having a major environmental impacts. Diminution world oil reserves and increasing environmental concern have induced found alternative and renewable energy resources called biodiesel. Biodiesel fuel from the vegetable oil, regarded as of the best candidate for the substitute diesel fuel in diesel engines because of the characteristics closer. The application of biodiesel has shown a positive impact in resolving these issues. This paper introduces some type of alternative fuel whose oils are potential sources of biodiesel. These types are crude palm oil (CPO), straight vegetable oil (SVO), waste cooking oil (WCO) and Jatrophacurcas(JPO). From the review, fuel properties are found to considerably different on density, viscosity, acid value, water content and flash point as compared with standard diesel. In conclusion, a long period of storage will reduce the quality of biodiesel does not matter what kind of conditions and environments that are exposed to. However, the rate of degradation of biodiesel can be slow if the right circumstances and environment provided.
\end{abstract}

\section{Introduction}

In late years, alternative fuels, energy efficiency, environmental security, energy conservation and management have become significant due to depletion of fossil fuel and environmental degradation. The alternative fuels or so called biodiesel can be better tried for diesel engine as compared to gas engines because of the construction of the diesel engine is very full-bodied and can operate under high compression ratio along with a substantial quantity of extra air. Biodiesel fuel will mix with soft wind in the combustion chamber to go through compression ignition. After the ignition process, performance and emission are produced. In this study, the focus would be on Storage and handling of biodiesel fuels whereby storage and handling are significant factors which can influence the quality of biodiesel as it is prone towards degradation as compared to fossil fuel. Normally, fuel is stored in a large vessel or tank at outdoor spaces so it is exposed to natural environmental condition where the properties would vary according to the conditions. The constituents which could speed the degradation of biodiesel include air (oxygen), light (UV), elevated temperatures, trace of metal, peroxide and the surface area between biodiesel and air. Biodiesel fuel is more hygroscopic compared to diesel fuel. It bears a natural inclination to absorb wet and water which tend to concentrate on the metal surface, favoring the corrosion [1].Even though the exposure of biodiesel towards light and air are cut back to the minimum level, but after some time, traces of air and light will still slide through and come in touch with the biodiesel inside. To make matter worse, heat from surrounding, presence of metals and water in the fuel may still rush up the oxidation procedure. Also, contamination by bacteria or fungi might result in the degradation of biodiesel and blends. Granting to the demand of international quality standard specifications, if the biodiesel is produced by crude palm oil (CPO), the point of free fatty acid and moisture content in CPO are the prime quality that should be evaluated. The quality of crude palm oil is largely limited by all kinds of factors such as from the nature of the parent tree, post-harvest handling, and error occurred during processing, shipping and storage technique [2]. 


\section{Experimental Setup}

In this area, the raw materials utilized as the main material is crude palm oil (CPO), straight vegetable oil (SVO), waste cooking oil (WCO) and Jatropha curcas (JPO).Blending process was needed to ascertain that the assortment of diesel and biodiesel is well mixed uniformly. Schematic view of blending process is described in figure 1. During blending process, the laboratory scale, blending machine was operated at $60^{\circ} \mathrm{C}$ and the mixture was stirred at $70^{\circ} \mathrm{C}$ for 1 hour. The rotating blade speed was set to preserve the same speed at 270 RPM [3].

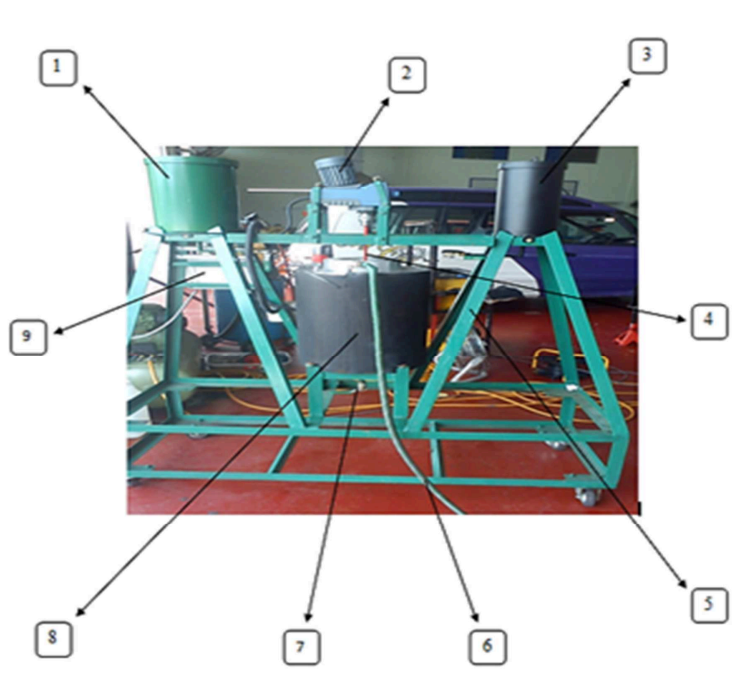

(a) Blending Machine

\begin{tabular}{|l|l|l|}
\hline Parts Number & Component & Function \\
\hline 1 & Diesel Tank & $\begin{array}{l}\text { Storage andlevel the } \\
\text { diesel }\end{array}$ \\
\hline 2 & Motor & Transmit motion to stir \\
\hline 3 & Biodiesel Tank & $\begin{array}{l}\text { Storage andlevel the } \\
\text { biodiesel }\end{array}$ \\
\hline 4 & Stir & $\begin{array}{l}\text { Stir the mixture diesel } \\
\text { and biodiesel }\end{array}$ \\
\hline 5 & Supporter & Support the device \\
\hline 6 & Water Inlet Pipe & $\begin{array}{l}\text { Use to inlet water at } \\
\text { the aroundtank }\end{array}$ \\
\hline 7 & $\begin{array}{l}\text { Water and Mixture } \\
\text { Outlet Pipe }\end{array}$ & $\begin{array}{l}\text { To take out the } \\
\text { mixture and water }\end{array}$ \\
\hline 8 & Mixture Tank & $\begin{array}{l}\text { Mixture diesel and } \\
\text { biodiesel }\end{array}$ \\
\hline 9 & Switch Box & $\begin{array}{l}\text { On the device and set } \\
\text { the temperature }\end{array}$ \\
\hline
\end{tabular}

(b) Component of Blending Machine

Fig.1. Illustrating the component blending process

The properties test considered to be investigated are included density, kinematic viscosity, water content, acid value and flash points test [4-7]. These properties test are established along the European Standard for Biodiesel (EN 14214) and American Society of Testing Materials (ASTM D6751). The density properties were measured by Metter Toledo Diamond Scale modelled JB703$\mathrm{C} / \mathrm{AF}$. In this inquiry, the kinematic viscosity of sample blend was measured by Viscolite 700 model VL700-T15. Kinematic viscosity is referring to the time consumed from a volume of sample (liquid form) to flow under gravity through a calibrated glass capillary Viscometer. The water content and acid value in the biodiesel sample were measured by Volumetric KF Titrator model v20 and titration process. The condition of acid value is shown as the amount (mg) of potassium hydroxide required to neutralize one gram of the biodiesel. During acid value measurement, the sample is titrated with alcoholic $\mathrm{KOH}$ using phenolphthalein as indicator. The flash point measured by Pensky-Martens PMA 4. 


\section{Results and Discussion}
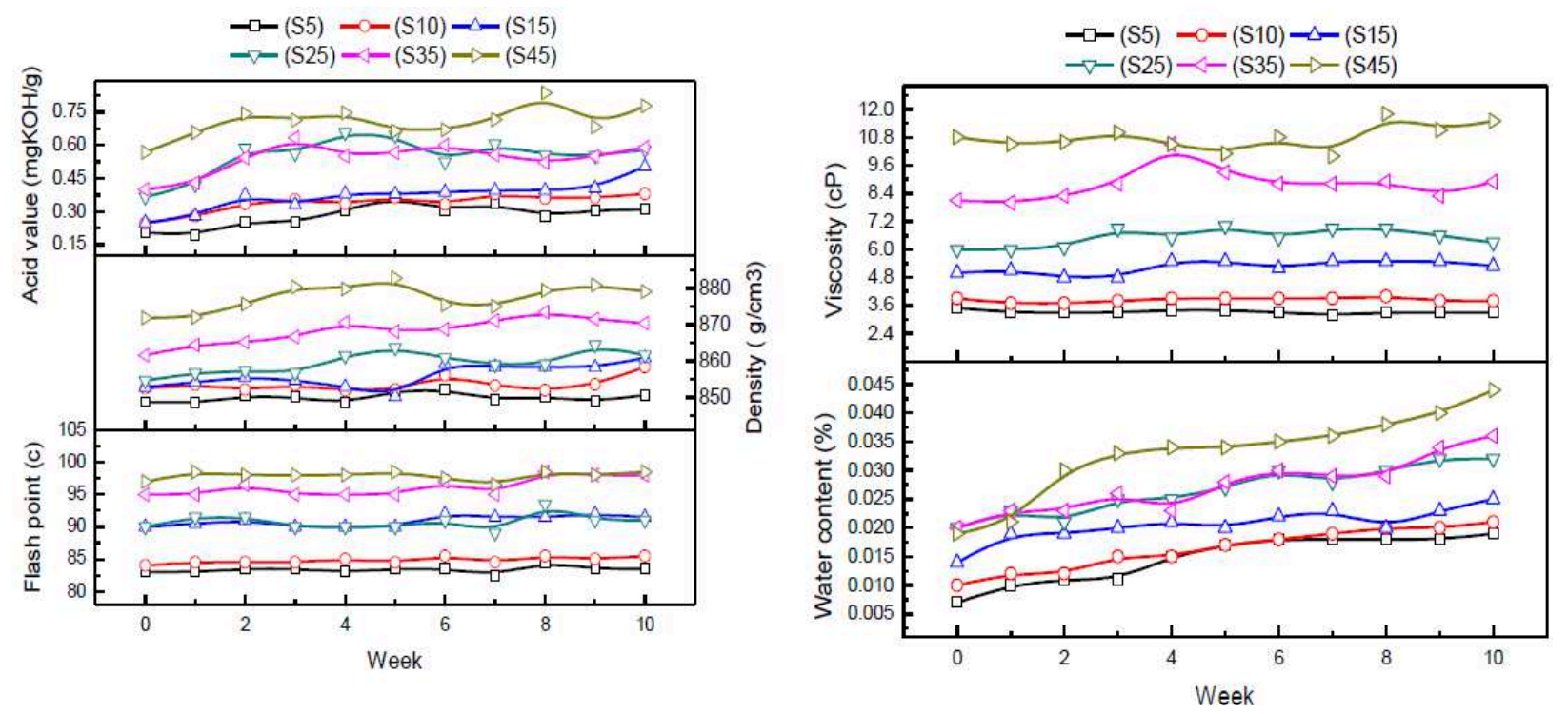

Fig.2 Effects of storage duration on straight vegetable oil [8]

Figure 2clearly demonstrates that increasing storage duration promotes high value for SVO properties such as flash point, density, kinematic viscosity, acid value and water content especially the higher SVO blending ratio S45. By measuring the properties of SVO, we obtain that the increasing ratio and storage duration are likely to provide. So we can state that the value of properties is keeping increased when the percentages of blending with SVO and longer storage duration are increased.

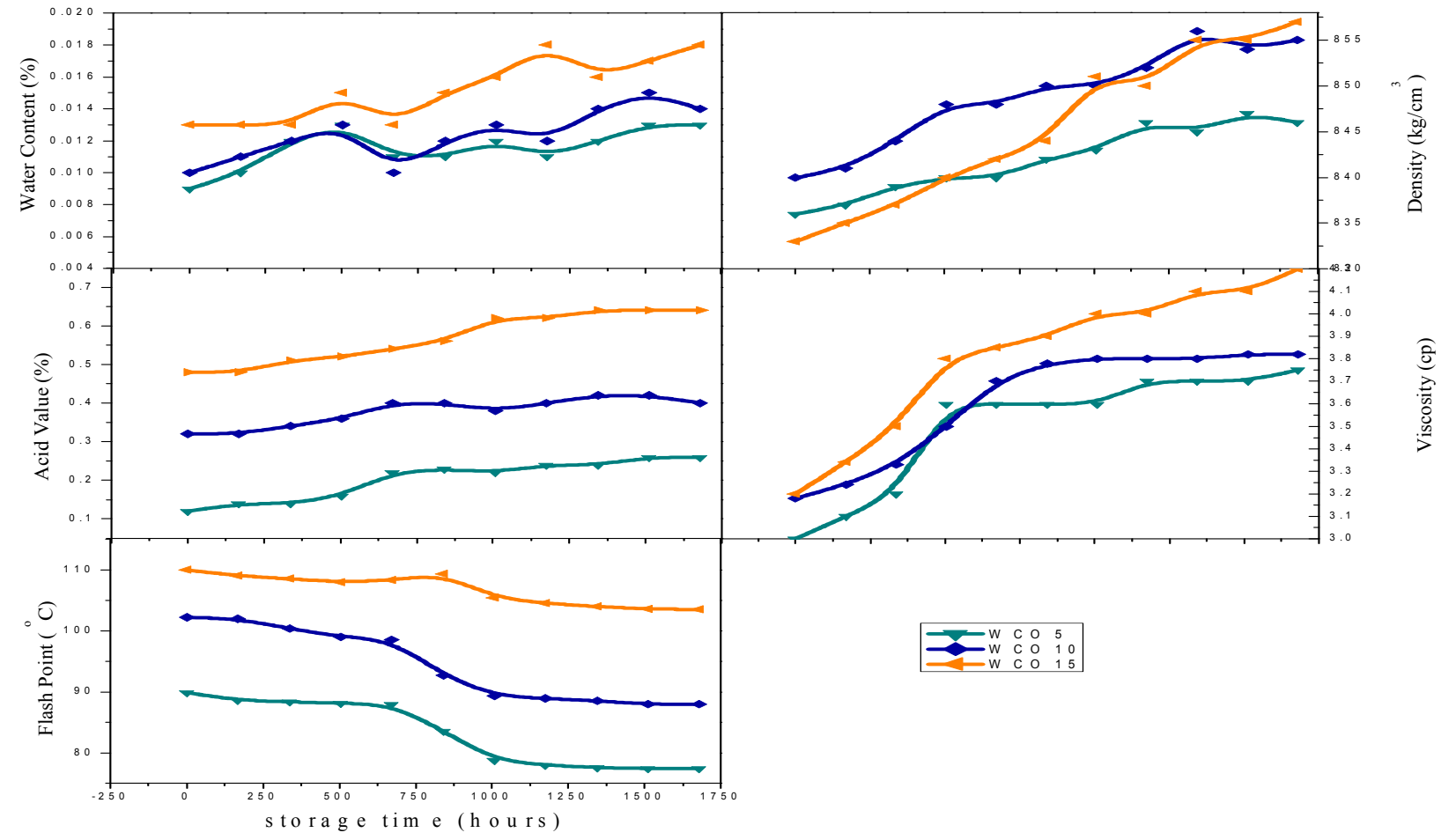

Fig.3 Effects of storage duration on waste cooking oil [9]

Figure 3clearly indicates that the increasing the storage duration of outdoor temperature encourage more biodiesel acid value, viscosity, flash point, water content, and density especially the higher biodiesel blending ratio WCO15. For all physical properties testing the increasing of blending ratio, thus predominantly influences the increasing of storage duration except the flash 
point testing it shown decreasing of blending ratio it influences the decreasing of fuel flash point, that at the time the storage duration at an outside temperature of biodiesel is expected to be deeply moved by the purified waste cooking oil methyl ester.

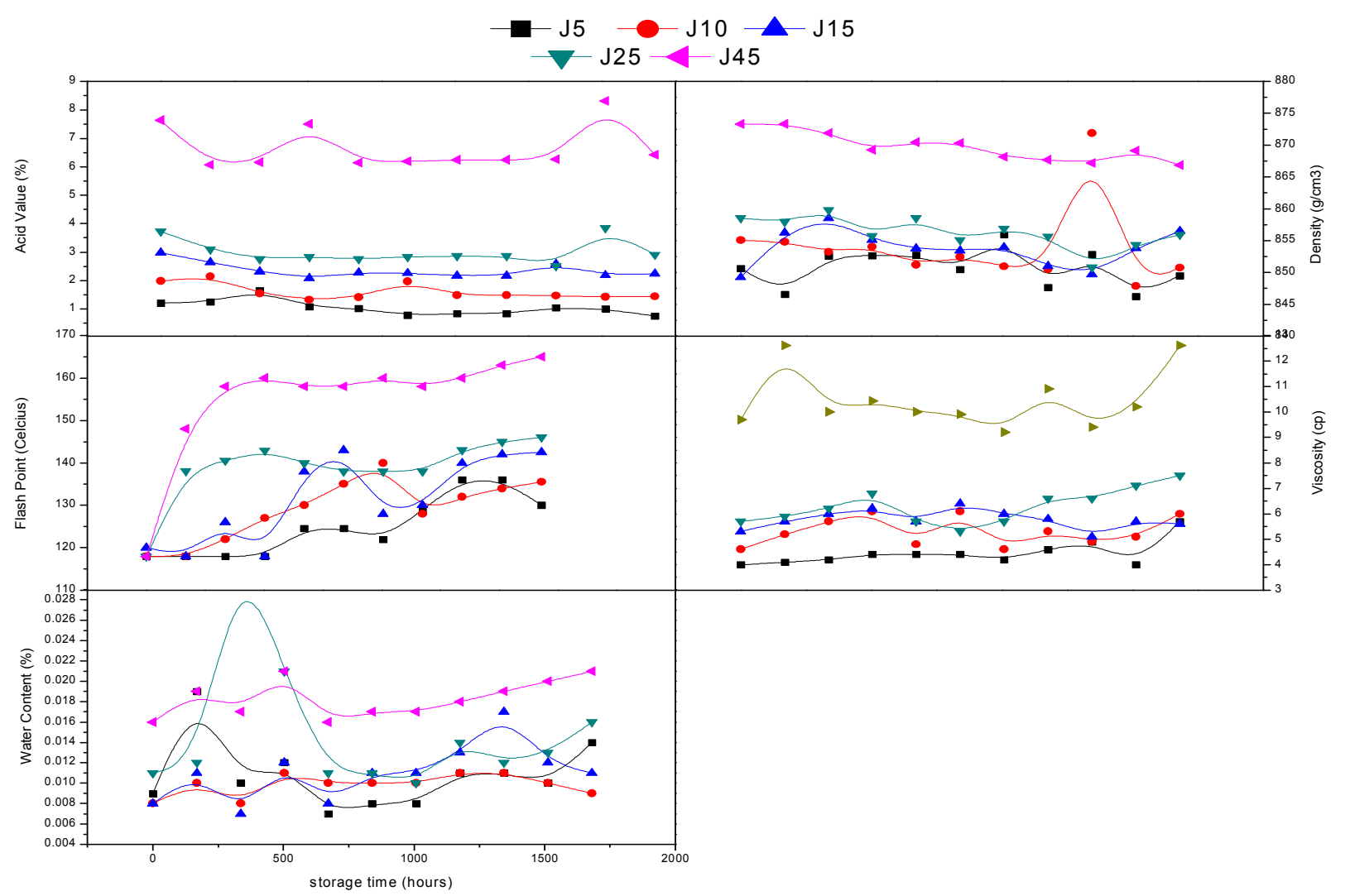

Fig.4 Effects of storage duration on crude Jatropha Curcas oil

As viewed in figure 4, the overall trend for the properties testing result in a continuous trend with a little trend of growth. J45 has a higher value of acid value at room temperature compare at ambient temperature. J5 has a lower value of acid value for an initial week at room and ambient temperature. With the boundary defined in ASTM D6751 and EN 14214 standards for biodiesel, the acid value which is below $0.5 \%$.All the samples show an increasing of acid value with increasing the duration time of storage.

\section{Conclusion}

It can be inferred that the biodiesel blend which are salted away in closed containers and indoor condition at ambient temperature contributed to a very significant increase than at low temperature for water content and acid value but not in the results of density, kinematic viscosity and flash point. Nevertheless, the result obtained still can be classified as small changes in physical properties of biodiesel blend for storage at both temperatures. The outcomes of this study agreed with the previous published data and it can be said that storage biodiesel at low temperature is suitable and has advantages more than storage at ambient temperature because the force on the physical properties is minimized and gives benefit in slowing down the degradation of biodiesel during storage.

\section{Acknowledgements}

The authors also would like to thank the Universiti Tun Hussein Onn and Ministry of Education, Malaysia for supporting this research under Fundamental Research Grant Scheme (FRGS) vot.E033. 


\section{References}

[1] Fazal MA, Haseeb ASMA, Masjuki HH. (2010).Comparative Corrosive Characteristics Of Petroleum Diesel And Palm Biodiesel For Automotive Materials. Fuel Process Technol, 91, 1308-15.

[2] S Mekhilef, SSiga. R Saidur.(2011). A Review On Palm Oil Biodiesel As A Source Of Renewable Fuel. Department Of Mechanical Engineering, University Of Malaya.

[3] Amir Khalid, Norazwan Azman, Hanis Zakaria, B. Manshoor, Izzuddin Zaman, Azwan Sapit, Mutalib Leman, "Effects of storage duration on biodiesel properties derived from waste cooking oil", Applied Mechanics and Materials, Volume 554, 2014, Pages 494-499, DOI: 10.4028/www.scientific.net/AMM.554.494.

[4] Amir Khalid, M.D. Anuar, Yusri Ishak, B. Manshoor, Azwan Sapit, Mutalib Leman, Izzuddin Zaman, "Emissions characteristics of small diesel engine fuelled by waste cooking oil", MATEC Web of Conferences, Volume 13, 2014, Article number 06006, DOI: 10.1051/matecconf/20141306006.

[5] Leung, D. Y. C., Koo, B. C. P., \& Guo, Y. (2006) Degradation of biodiesel under different storage conditions. Bioresource technology, p p. 250-6.

[6] Berrios, M., Martín, M. a., Chica, a. F., \& Martín, a. (2012) Storage effect in the quality of different methyl esters and blends with diesel. Fuel, pp. 119-125.

[7] Meher, L. C., VidyaSagar, D., \&Naik, S. N. (2006). Technical Aspects Of Biodiesel Production By Transesterification-A Review. Renewable And Sustainable Energy Reviews, 10 (3), 248268. Do: Http: //Dx. Doi. Org/10.1016/J.Rser.2004.09.002

[8] Amir Khalid, Norrizal Mustaffa, B. Manshoor, Hanis Zakaria, Ahmad Jais Alimin, Mutalib Leman, A. Sadikin, "The Comparison of Preheat Fuel Characteristics of Biodiesel and Straight Vegetable Oil", Applied Mechanics and Materials Vols. 465-466 (2014), Trans Tech Publications, Switzerland, pp 161-166.

[9] K Syahrullail, S., Nakanishi, K., Kamitani, S., 2005. Investigation of the effects of frictional constraint with application of palm olein oil lubricant and paraffin mineral oil lubricant on plastic deformation by plane strain extrusion. Japanese Journal of Tribology, Volume 50, Issue 6, Pages 727-738. 